\title{
内耳メラニンの有無による音響受傷性の相違
}

\author{
広島大学医学部耳鼻咽喉科学教室（主任：原田康夫教授） \\ 川 和幸

\section{SUSCEPTIBILITY OF ORGAN OF CORTI WITH OR WITHOUT MELANIN TO ACOUSTIC OVERSTIMULATION}

\section{KAZUYUKI KAWAGUCHI, M.D.}

Department of Otorhinolaryngology, Hiroshima University School of Medicine, Hiroshima

Albino and pigmented guinea pigs were compared in terms of susceptibility to acoustic trauma. The animals were exposed to a $4 \mathrm{kHz}$ pure tone of $120 \mathrm{~dB}$ for $60 \mathrm{~min}$. N1 thresholds of CAP were measured before and after the acoustic exposure. Changes in the outer hair cell and stria vascularis were studied using SEM and TEM. After acoustic trauma, Nl thresholds were more elevated in the albino than in the pigmented guinea pigs. Also, pathological changes in the outer hair cell and stria vascularis were more severe in the albino animals. A noteworthy finding in the stria vascularis was that the melanin in intermediate cells had moved into marginal cells. This melanin migration may be possibly involved in mechanisms underlying prevention of acoustic trauma.

Key words : メラニン，音響外傷，蝸牛

緒 言

内耳の膜迷路に色素が存在することは，1851年 Cortill の牛と羊についての報告以来，上卜を含種々 の動物に扔いて確認されている ${ }^{23)}$. 1931年 Wolff(1)に より，この色素がメラニンであることが指摘され，内 耳内のメラニンの存在意義について，研究がなされる ようになった ${ }^{56)}$. 蝸牛では, 主として血管条にメラニ
ンが認められて扔り，このメラニンと聴覚機能との関 係が検討されてきだ78). ヒトでは, 内耳のメラニン量 と虹彩メラニン量が比例することが，Bonaccorsi ${ }^{91} に$ より証明され、これに関連して虹彩の色の違いによる 音響受傷性の相違について，臨床的研究がなされてい $3^{10111}$. しかしながら, 音響外傷後の聴覚の時間的経過 及びその内耳形態の面での相違を, 内耳メラニンとの

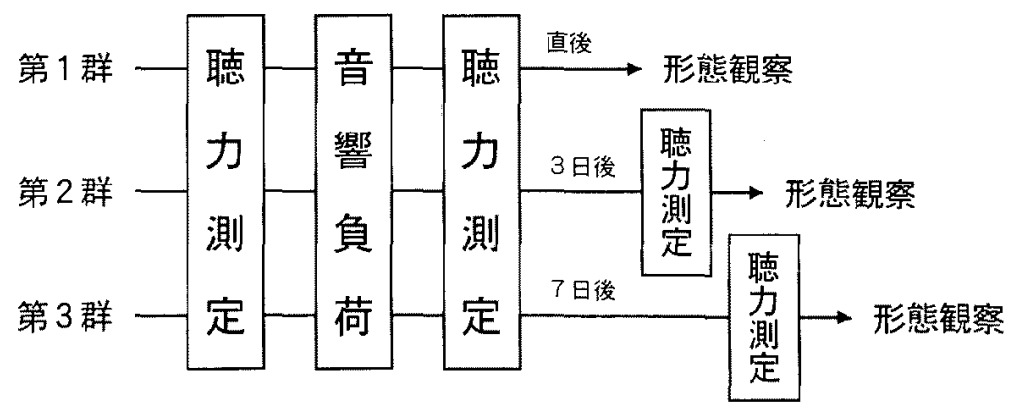

図 1 実験概要 
関係において論じた研究は少ない，本研究は，内耳の なかでもとくに血管条に着目し，血管条メラニンの有 無と音響受傷性の関係を聴賞生理学的, 微細形態学的 に検索し，蝸牛におけるメラニンの存在意義について 知見を得たので報告する。

\section{実験方法}

実験動物には，内耳にメラニンの存在しないハート レイ系モルモットと, メラニンの存在する黒目有色モ ルモットを，各々15匹ずつ使用した．動物はプライエ ル反射正常で体重 200〜250g のものを用いた．実験の 概要を図 1 に示す．白色モルモット，有色モルモット をそれぞれ 5 匹ずつの 3 群に分け，まず音響負荷前に， 鼓室外誘導で蝸牛神経活動電位 (cochlear action potential，以下 CAP)を指標として聴覚レベルを計測 した.この後，音響負荷を行い，第 1 群は音響負荷直 後, 第 2 群は負荷 3 日後, 第 3 群は負荷 7 日後に CAP を再度測定した後, 断頭して蝸牛を摘出し, 蝸牛有毛 細胞の障害状態を走査型電子顕微鏡 (以下 SEM) で, また血管条形態は透過型電子顕微鏡 (以下 TEM) を用 いて観察した。

\section{1) 聴力測定}

聴力測定は音響負荷前, 音響負荷直後, 音響負荷 3 日後， 7 日後に行った。ネンブタール尽 $(30 \mathrm{mg} / \mathrm{kg}$, ip) 麻酔下に，外耳道を観察し耳垢がないことを確認した 後, 耳後部を切開し骨部外耳道皮下を露出, 外耳道深 部に向かって針電極を約 $2 \mathrm{~mm}$ 刺入し，これを近位電 極とした。遠位電極は耳後部切開創下端に，接地電極 は前額正中に設置した。刺激音は，立ち上がり $1 \mathrm{msec}$, plateau $3 \mathrm{msec} の$ short tone burst を用い，外耳道入 口部より $1 \mathrm{~cm}$ の距離に置いたスピーカー (TDH-49) より与えた。増幅器 (日本光電 $\mathrm{AB}-671 \mathrm{~V}$ ) のフィルタ 一は, time constant $0.003 \mathrm{sec}$, high cut $1 \mathrm{kHz}$ とし, 日本光電 ATAC-350 を通して, 解析時間 $10 \mathrm{msec}, 200$ 回加算を行った. 聴力は, $1,4,6,8 \mathrm{kHz}$ について CAP N1の振幅を指標としてその域値を計測した.

2）強大音響負荷

メラニンの有無による音響に対する受傷性の差をみ るためには，各々の動物で，ほぼ同じ部位でのコルチ 器の形態観察を行う必要がある。このため, 音響負荷 には純音を用い，これによる障害部位を限局させた。 純音発生装置には TRIO AUDIOMETER AS28 を用 い, $36 \times 35 \times 50 \mathrm{~cm}$ の大きさの木箱に取り付けたスピ 一カー(ONKYO D-3520A) より $4 \mathrm{kHz}$ の純音を発生

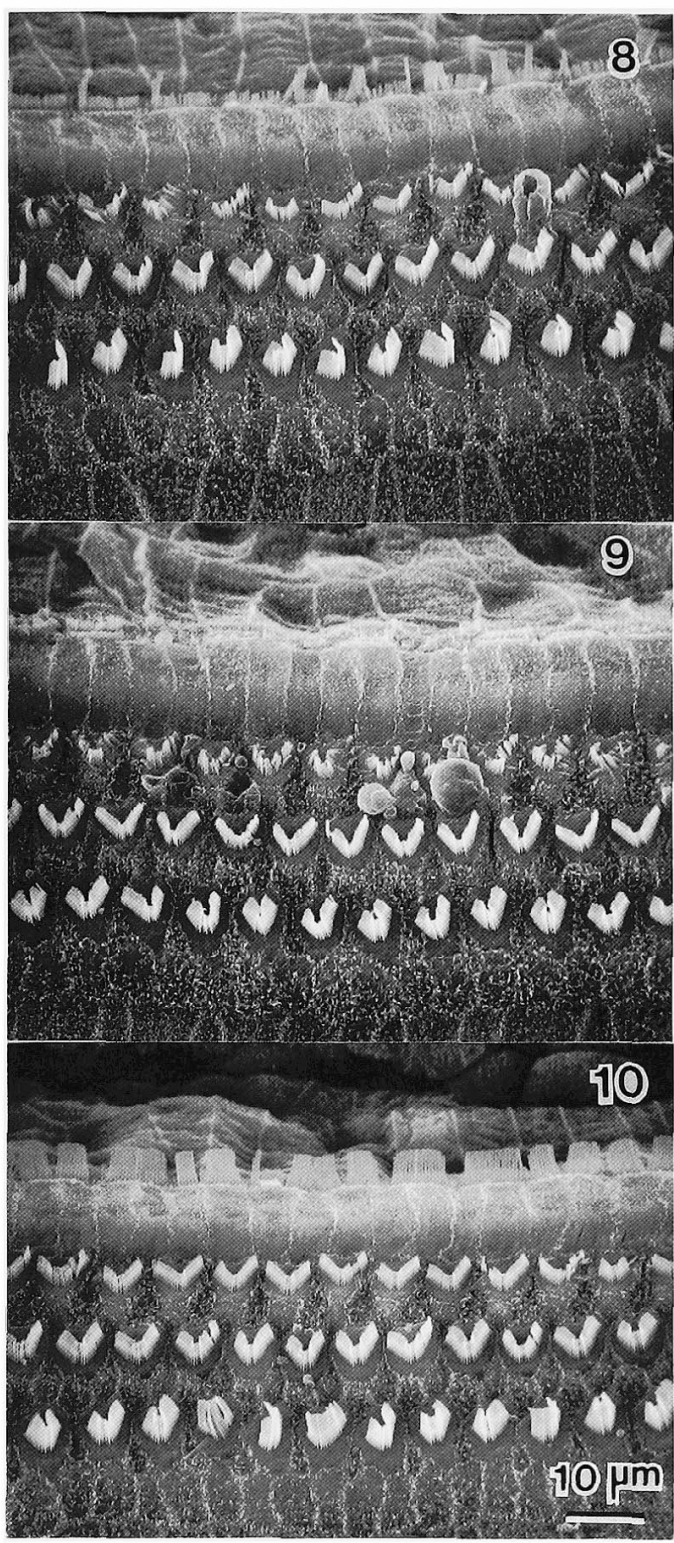

図 2 上方よりそれぞれ前庭空から $8,9 ， 10 \mathrm{~mm}$ の部位の外有毛細胞の SEM 像. $9 \mathrm{~mm}$ の部 位を中心とした障害を認める。

させ,モルモットの外耳道の位置で $120 \mathrm{~dB}$ になるよう 更正して，無麻酔下のモルモットに60分間曝露した。

3) 形態学的観察

音響によるコルチ器有毛細胞の障害部位は，周波数 特異的に前庭空からの距離で決まっていると言われて おり, $4 \mathrm{kHz}$ での主たる障害部位は前庭空から約 $9 \mathrm{~mm}$ の部位とされている ${ }^{(2) ~ 15)}$. 今回の実験でもコルチ器有 


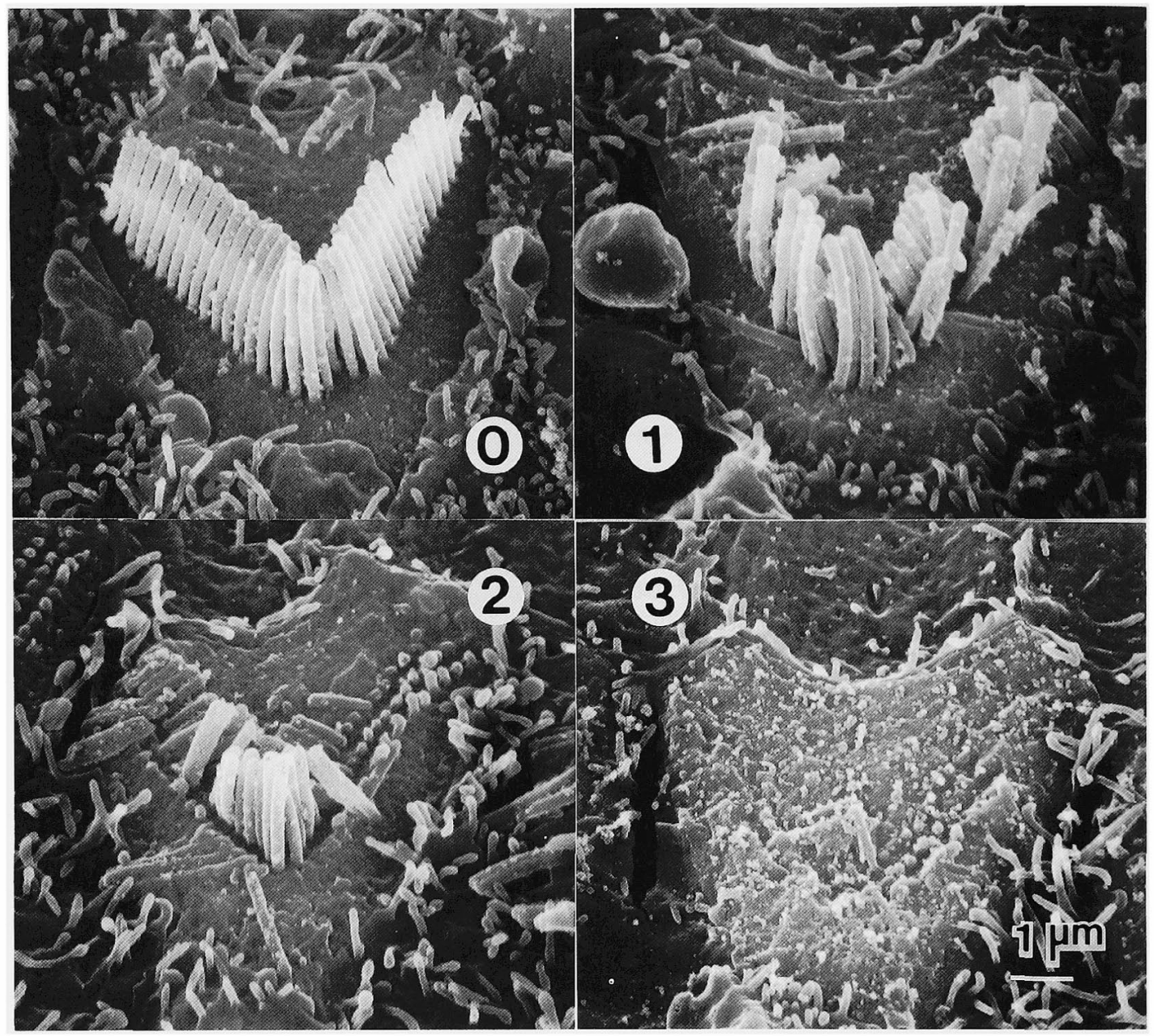

図 3 外有毛細胞障害度分類， 0 から 3 までの 4 段階に分類した。

毛細胞の障害は,図 2 に示すように前庭空より約 $9 \mathrm{~mm}$ の部位を中心として認められた。このため, 形態学的 観察は，前庭空より約 $9 \mathrm{~mm}$ の部位の外有毛細胞及び 血管条を観察対象とした，強大音響負荷直後，負荷 3 日後, 負荷 7 日後において聴力測定をした後, $2.5 \%$ グ ルタールアルデヒドで左心室より灌流固定を行い，側 頭骨を摘出した。中耳骨胞を開放し，同固定液で内耳 灌流を行った後，蝸牛外側骨壁を除去し，前庭空より 約 $9 \mathrm{~mm}$ の部位の血管条を摘出した. 取り出した血管 条は $1 \%$ 四酸化オスミウムで後固定後，3\%酶酸ウラ ニルによるブロック染色, さらに上昇エタノール系列 で脱水後, エポン $812 に$ 包埋した。 その後超薄切片作製, ウラン一鉛による二重染色後，TEM (JEM100CXII) で観察した。血管条を取り出した後の蝸牛は， $2 \%$ 夕
ンニン酸，1\%オスミウムによる後固定後，上昇エ夕 ノール系列で脱水，次いで酢酸イソアミルで置換した 後, 臨界点乾燥 $\left(\mathrm{CO}_{2}\right)$, 白金イオンスパッタコーティ ングを経て SEM (HITACHI S-800) にて観察した。 外有毛細胞の障害を定量的に評価するために，下記の ような外有毛細胞障害度分類を作製し，これにより前 庭空より 8，9，10mm の各部位における 3 列の外有毛 細胞各列10個ずつ計30個を評価し，その合計を各動物 の障害スコアとした。（図 3 )

0 : 障害が全くみられない正常形態

1: 聴毛の配列の乱れはあるが, 消失はみられないと いつた軽度の障害

$2:$ 聴毛の一部消失を伴う中等度の障害

$3:$ 聴毛の全消失を伴う高度の障害 


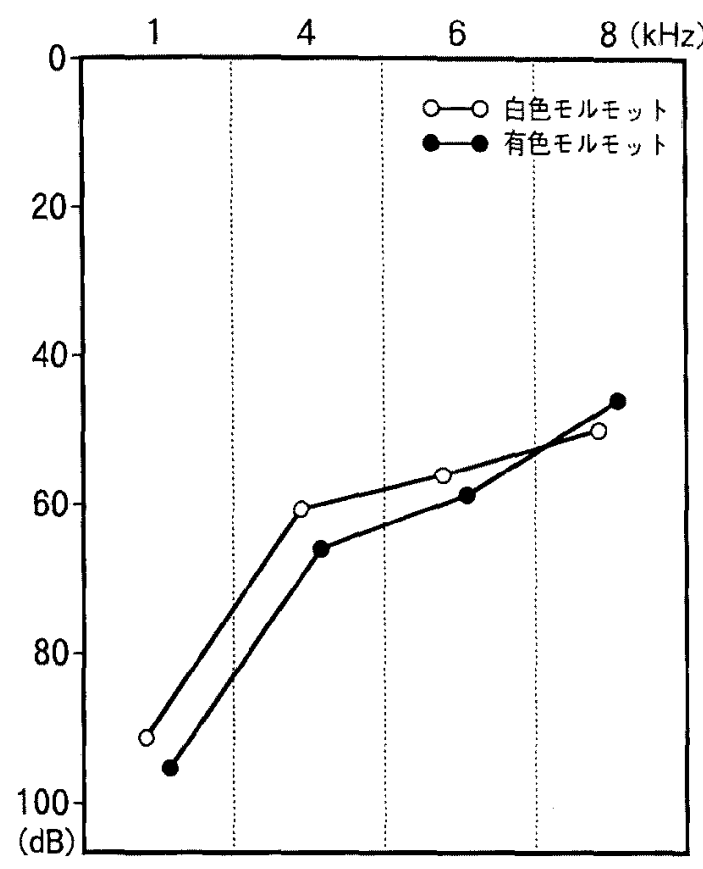

图 4 音響負荷前のオージオグラム。両者ともに 低音急壁型の聴力を呈し, 有意差は認めら れない。

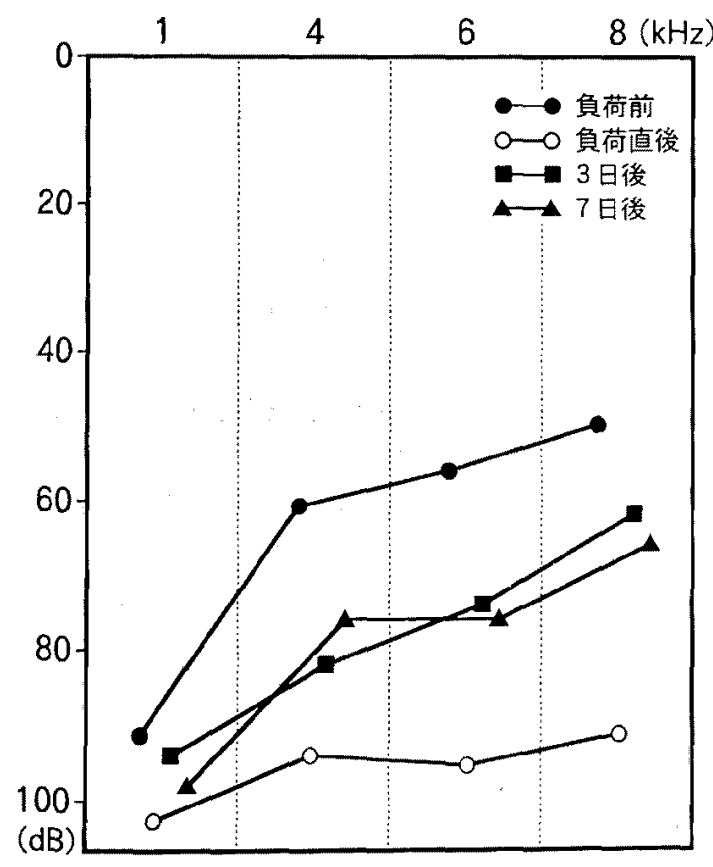

图 5 白色モルモットのオージオグラム

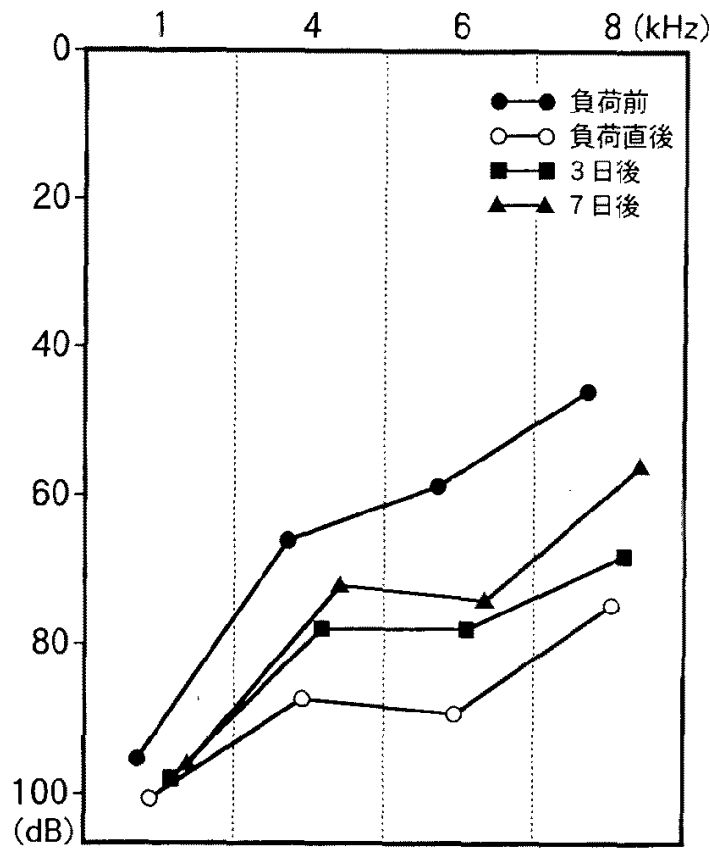

図6 有色モルモットのオージオグラム

例えば, 図 2 の $9 \mathrm{~mm}$ では, 障害度 3 は 0 個, 2 は 6 個, 1 は 8 個，0は16個で，障害スコアは20となる。

\section{実験結果}

1）聴力変動

音響負荷前の聴力は，白色モルモット，有色モルモ ットいずれも低音漸傾型の㯖力像を呈していた。ただ し白色モルモットの聴力の方が若干良好な傾向を認め たが、有意の差はなかった（図 4)。

白色モルモットの聴力域值は，いずれの周波数にお いても音響負荷直後には，高度に上显したが，3日後 にはある程度の聴力回復がみられた。しかし7日後ま でにはそれ以上の回復はほとんどみられなかった。こ れに対して有色モルモットでは，負荷直後には琙值の 上昇がみられたものの，その程度は白色モルモットに 比べてやや小さく，3 日後から 7 日後にかかけての聴 力の回復も大きかった（図 5,6 ）。

さらに，有色モルモット，白色モルモットでの音響 負荷前後の聴力変動の差を見るため, 負荷前の各動物 の聴力域值を 0 とし，負荷後の域値上昇の平均值を比 較した(図 7).この結果 $4 \mathrm{kHz}$ の音響負荷直後，負荷 3 日後の域值上昇の程度は, 白色モルモットに比べて 有色モルモットの方が有意に小さく（p<0.01），7日 

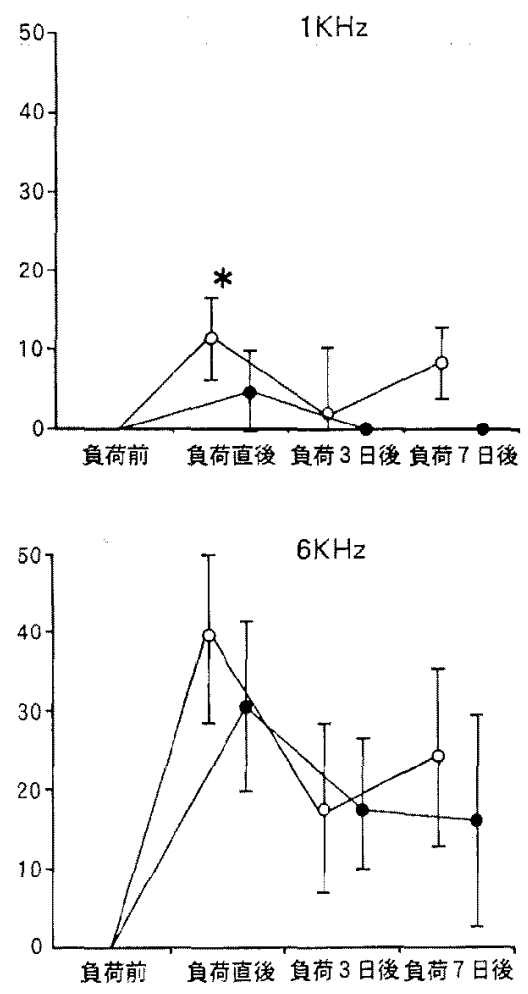
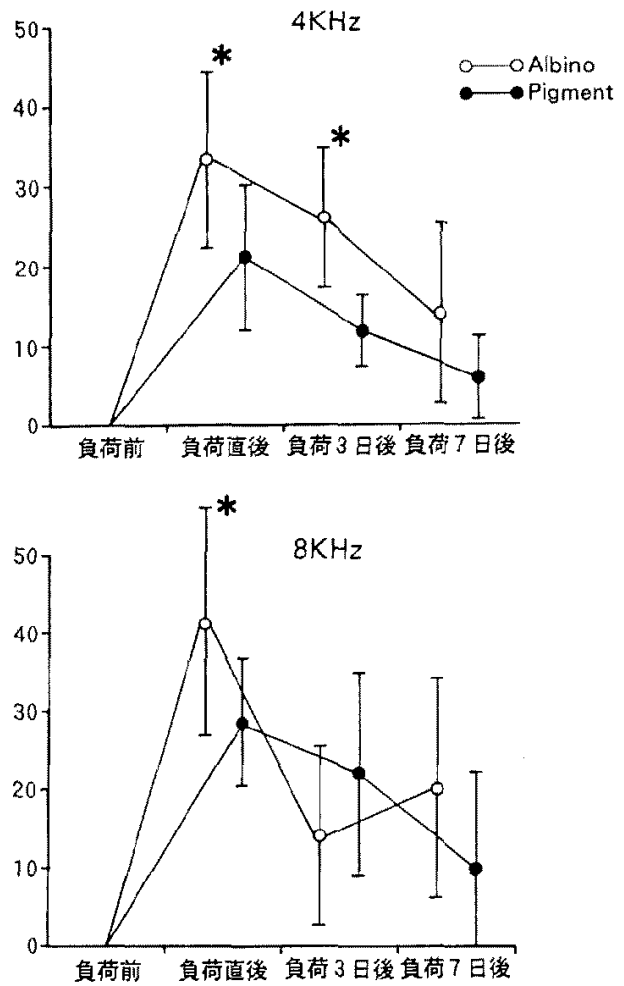

図 7 各周波数における強大音響負荷前值を 0 としたときの聴力域値変動

$$
(*: \mathrm{p}<0.01)
$$

表 1 外有毛細胞障害スコア表

$8,9,10 \mathrm{~mm}$ の各部位 30 個の外有毛細胞 を,図 3 の障害度分類に従ってスコア化し， その総計をその動物の障害スコアとし，各 グループ $(\mathrm{n}=5)$ の平均をまとめた。

\begin{tabular}{|c|c|c|c|c|c|c|}
\hline & \multicolumn{3}{|c|}{ 白色モルモット } & \multicolumn{3}{|c|}{ 有色モルモット } \\
\hline & $8 \mathrm{~mm}$ & 9 & 10 & 8 & 9 & 10 \\
\hline \multirow{3}{*}{$\begin{array}{l}\text { 負荷直後 } \\
\text { 平 均 } \\
\text { 標準偏差 }\end{array}$} & & & & & & \\
\hline & 8.3 & 16.5 & 8.0 & 10.0 & 14.8 & 7.8 \\
\hline & 4.7 & 14.9 & 2.0 & 9.7 & 11.3 & 4.1 \\
\hline 負荷 3 日後 & & & & & & \\
\hline 平 均 & 7.3 & 16.3 & 6.8 & 13.3 & 15.5 & 4.8 \\
\hline 標準偏差 & 6.4 & 11.1 & 5.0 & 14.9 & 9.6 & 2.0 \\
\hline 負荷 7 日後 & & & & & & \\
\hline 平均 & 8.6 & 17.6 & 7.0 & 7.5 & 12.8 & 5.0 \\
\hline 標準偏差 & 7.4 & 5.9 & 3.0 & 3.9 & 4.2 & 1.9 \\
\hline
\end{tabular}

後での域值上昇も小さかった! また，その他の周波数 でも，同様の傾向がみられたが, 1 および $8 \mathrm{kHz}$ の音響 負荷直後を除いて有意差を認めなかった。
2) 形態学的変化

a) 的生有毛細胞の障害

$\mathrm{SEM} に よ る$ 観察では, $4 \mathrm{KHz}$ 純音負荷後のコルチ器 障害は, 前庭空より $9 \mathrm{~mm}$ の部位を中心としてみられ た（図 2)。とくに外有毛細胞では内側第1列，2列， 3 列の順に障害が強い傾向が見られた，障害程度の比 較のために, $9 \mathrm{~mm}$ の部位の外有毛組胞障害スコアの平 均をみると, 音響負荷直後は白色モルモット 16.5 , 有 色モルモット14.8で 3 日後はそれぞれ $16.3 ， 15.5 ， 7$ 日後は $17.6,12.8$ といずれの時期においても白色モル モットの障害の方が強い傾向があった(表 1). 経時的 な障害の変化は, 白色モルモ゙ットでは急荷直後, 負荷 3日後, 7日後ともに障害程度はほほ同様であったの に対して, 有色モルモットでは負荷 7 日後のスコアが 12.8 と負荷直後の 14.8 よりも小さくなっていた.

b) 血管条の障害

正常の血管条は, 辺縁細胞, 中間細胞, 基底細胞の 3 種の細胞により構成されている。辺縁細胞は最も内 リンパ腔側に位置しており, 小胞体, ゴルジ装置, ミ トコンドリアといつた細胞内小器官が豊富なため, 細 


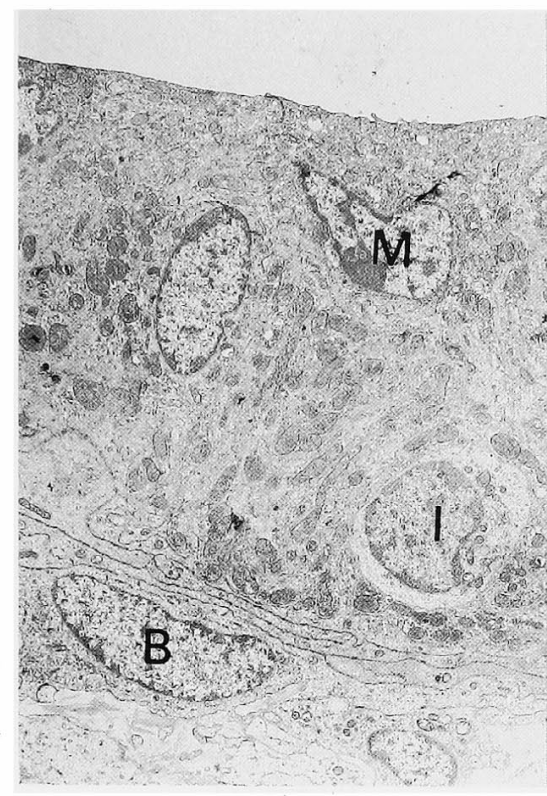

Albino

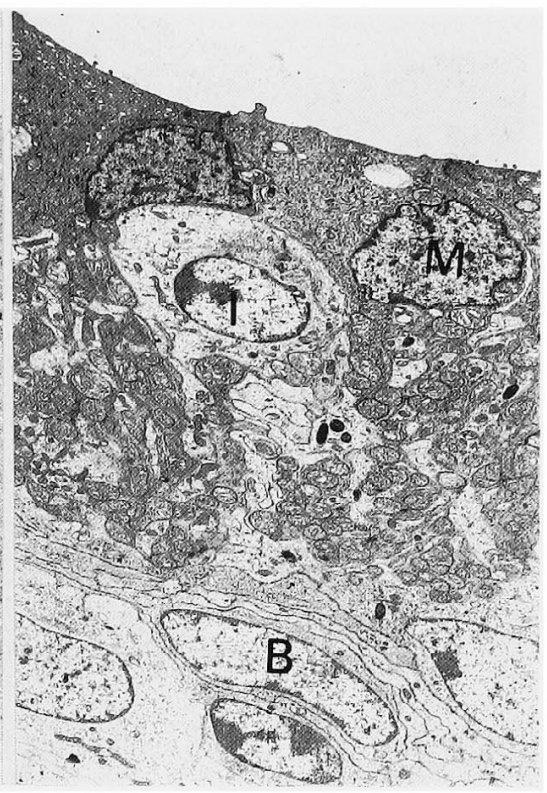

Pigmented

図 8 正常血管条 TEM 像

内リンパ腔側より辺縁細胞 ( $\mathrm{M})$, 中間細胞 (I), 基底細胞 (B) の 3 層 の細胞より構成される。有色モルモットでは中間細胞にメラニンを認め る. 左: 白色モルモット, 右: 有色モルモット $(\times 1800)$ $\mathrm{M}$ : 辺縁細胞 $\mathrm{I}$ : 中間細胞 $\mathrm{B}$ : 基底細胞

胞質全体の電子密度は高かった. その特徵的形態は, 著明に発達した基底嵌入で，この細胞の下層に存在す る中間細胞, 基底細胞との間で interdigitation を形成 し，この部位には多数のミトコンドリアが存在してい た. 辺縁細胞の自由表面には少数の微絨毛が, また自 由表面直下には vesicle がみられた。

中間細胞は, 辺縁細胞の深層に存在する細胞で, 辺 緑細胞と比べると細胞内小器官が少なく, その細胞質 の電子密度は低かった，血管条におけるメラニンは主 としてこの細胞内に局在しており, 白色モルモットと 有色モルモットの大きな違いはこのメラニンの有無で あった。

基底細胞は偏平で, 最も深層に位置しており,この 細胞にもメラニンは存在した. 電子密度は中間細胞と 同程度であった。(図 8)

音響負荷直後の白色モルモットでは, 辺緑細胞の細 胞間隙の軽度の拡大がみられたが, 細胞内小器官の変 化は軽微であった。また中間細胞, 基底細胞では著変 を認めなかった。 有色モルモットでは, 細胞間隙の拡 大はなく, 一部の中間細胞で内部のメラニンが内リン
パ腔側への移動が認められるものの, その他には変化 はなく，音響負荷直後における血管条の傷害はほとん どみられなかった(図 9 ). 負荷 3 日後になると(図10), 白色モルモットに見られた血管条障害は高度となり, 辺緑細胞の核は変形し, 細胞質には多数の小空胞が出 現した. 細胞間隙の拡大も進行し, 辺縁細胞と中間細 胞の間にまで及んでいた。これに比べて, 有色モルモ ットでの障害は軽度で, 辺緑細胞レベルまでの細胞間 吵の軽度拡大と, 中間細胞内に扔けるメラニンの内リ ンパ腔側への移動を認めるのみであった。

負荷 7 口後, 白色モルモットでは, 辺緑細胞で細胞 間隙の軽度拡大がみられたものの, 細胞形態そのもの はほほ正常に復していた。一方, 有色モルモットでは, メラニンの移動は音響負荷 3 日後と同様にみられてい たが, その他はほほ正常形態に復していた（図11).

以上の結果から, 音響による血管条の形態的障害は, 音響負荷 3 日後に最も高度となり, 白色モルモットと 有色モルモットを比較すると, 血管条にメラニンを持 つ有色モルモットの方が, 全経過を通じて障害が軽度 であることが明らかとなった。 


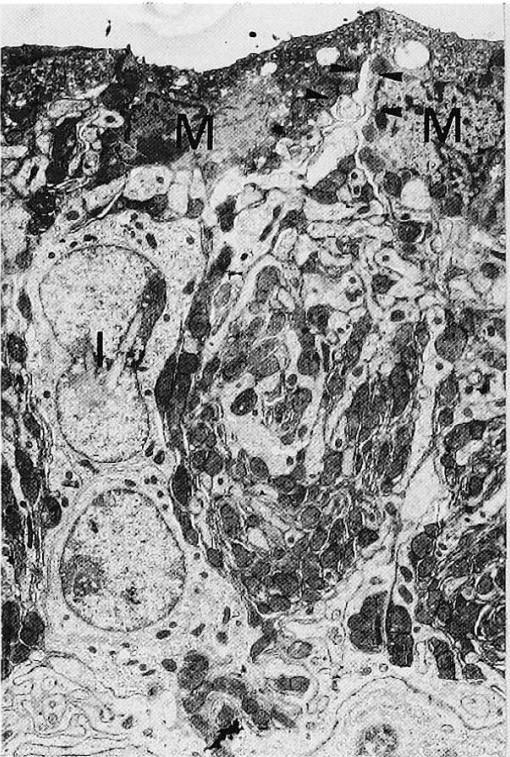

Albino

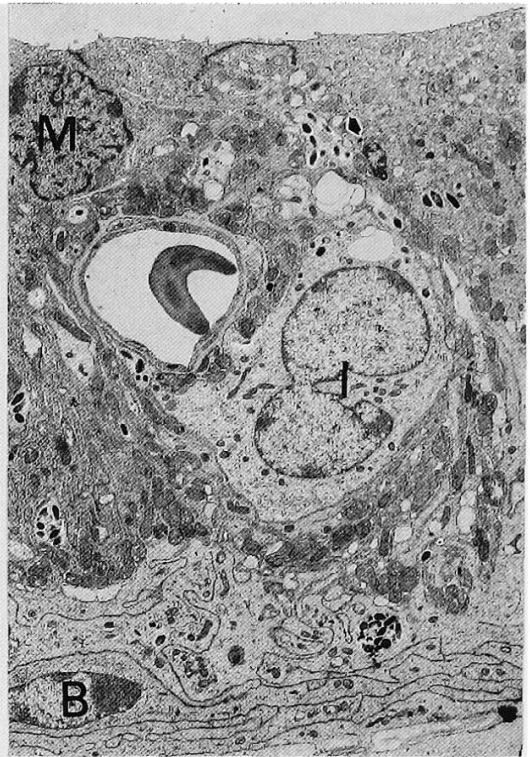

Pigmented

図 9 音響負荷直後の血管条

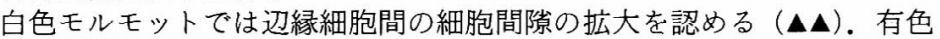
モルモットでは中間細胞内メラニンの, 内リンパ腔側への移動を認める (†). $(\times 1800)$

$\mathrm{M}$ ：辺縁細胞 I：中間細胞 $\mathrm{B}$ ：基底細胞

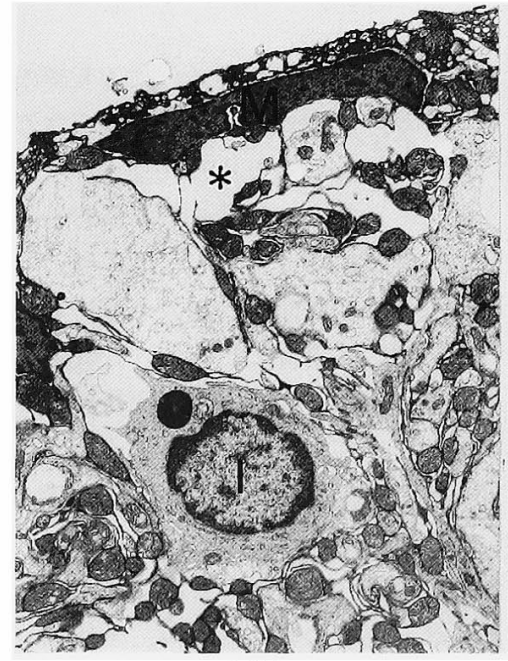

Albino

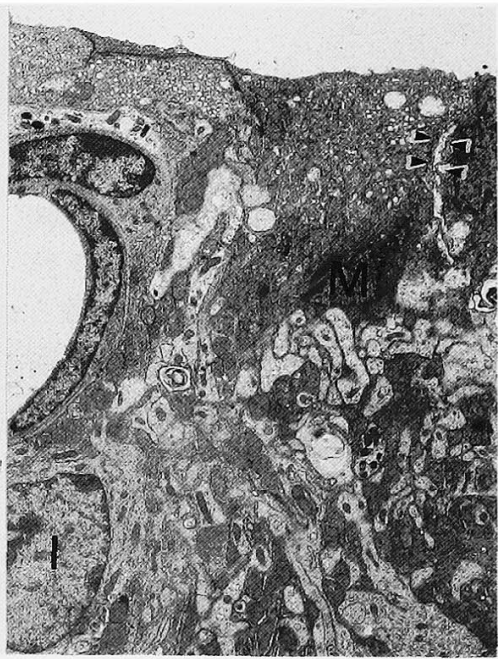

Pigmented

図10 音響負荷 3 日後の血管条

白色モルモットの障害は高度で, 細胞間隙の拡大 $(*)$ や辺縁細胞 内の空胞形成は著明となる. 有色モルモットでは辺縁細胞間の細胞 間隙拡大を認める $(\boldsymbol{\Lambda} \mathbf{\Delta}) .(\times 1800)$

$\mathrm{M}$ ：辺縁細胞 I：中間細胞 $\mathrm{B}$ ：基底細胞 


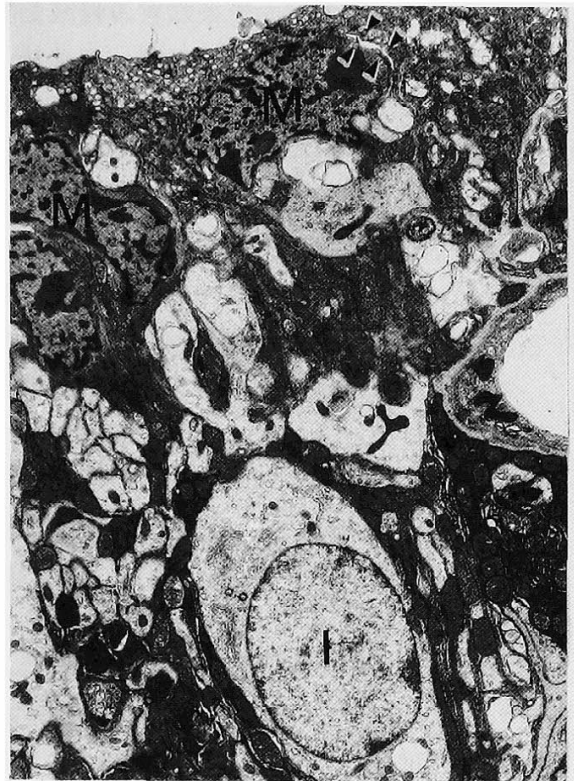

Albino

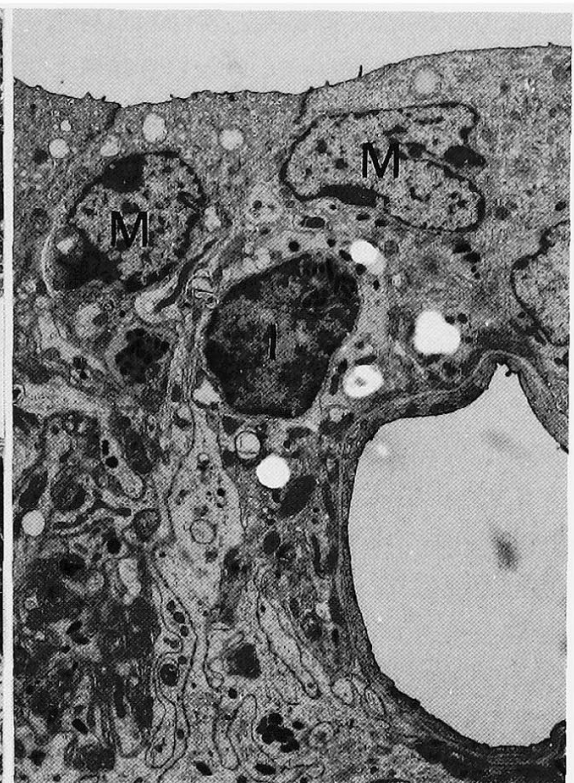

Pigmented

図11音響負荷 7 日後の血管条

白色モルモットではまだ辺緑細胞間の細胞間隙の拡大が認められる

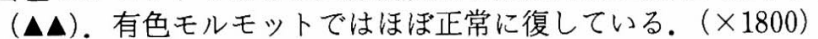

$M$ : 辺縁細胞 I：中間細胞 B：基底細胞

考按

蝸牛の音響障害の機序については，ヒトもふくめて 種々の動物で生理学的あるいは形態学的に研究されて いる16) 19). しかしながら, 蝸牛におけるメラニンの存 在の有無という観点から, 受傷性の違いを検討した研 究は少なく, とくに形態学的な面からの研究はまれで ある。

蝸牛内のメラニンは, 主に血管条に存在することが 知られておう ${ }^{2) 3}$, Conlee ら ${ }^{2)}$ は 5 種類の動物 (ネコ, モルモット，ウサギ，ネズミ，イタチ）の血管条を, 有色種と白色種でそれぞれ光顕, 電顕的に観察し, こ のうち有色モルモットが最もメラニンが豊富であり, 白色モルモットではメラニンを認めなかったと報告し ている. 本研究においても，TEMによる観察で，白色 モルモットの血管条にはメラニンが存在せず, 有色モ ルモットでは主に中間細胞と基底細胞にメラニンが存 在することを確認した，以上より，モルモットを実験 動物として，血管条におけるメラニンの有無による音 響障害に対する受傷性の差を白色モルモットと有色モ ルモットを用い追求した。

音響負荷前後の聴力測定の結果，音響負荷前には，
聴覚域値に有意の差はないものの, 音響負荷直後及び 負荷 3 日後には, 有意の差をもって, 白色モルモット の域値が上昇していた。負荷 7 日後には有意の差はな いものの, 白色モルモットの域值の上昇が有色モルモ ットのそれよりも大であった。このことから音響に対 する受傷性は，白色モルモットの方が大きいと考えら れた。

Conleeらは20021)，モルモットにband noise を負荷 乙, 負荷前, 負荷後 90 分, 7 日後に聴力を CM (cochlear microphonics) を指標として測定し，本研究とほほ同 様の結果を報告している。

一方，ヒトでは，蝸牛内メラニン量が虹彩メラニン 量に比例するといつた点 ${ }^{9)}$ から，虹彩の色と音響障害 との関係についての研究がなされている. Carter ら ${ }^{10)}$ は，鉄砲による音響に暴露されることの多い兵士の聴 力検査を行い, 虹彩にメラニンの豊富な brown eye の 人より,メラニンのそしい blue eye の人のほうが, 聴 力域値が高いとしている。 またTota \& Bocci は ${ }^{11)}$, 正常聴力者に対する音響負荷による TTS (temporary threshold shift) を計測し, brown eye の人のほうが blue eyeの人より有意に TTS が小さかったとしてい 
る、これらの報告は, 今回の実験結果, すなわち有色 モルモットの方が音響障害を受けにくいという結果と 一致する。つまり内耳, 特に螖牛血管条に存在するメ ラニンが, 強大音響からの内耳防御機能を果たしてい るのではないかという仮説がなりたつ。

本研究ではこうした仮説を, 形態学的側面から確認 するために，外有毛細胞と血管条を観察した，外有毛 細胞の障害は，その程度を客観的に評価するためスコ ア化し, 経時的に平均值学算出したが, 白色モルモッ 卜，有色モルモット雨群間に有意差を認めなかったも のの，白色モルモットのほうがいずれの時期において も障害の程度が強い傾问が確認された。また有色モル モットでは負荷 7 日後には負荷直後に比べて障害スコ アは小さくなっていた。このことは外有电細胞の障害 は，その程度炕上っては回復する可能性を示唆してい る。今回の障害度分類スコア1，すなわ方感賞毛の配 列の乱れはあるものの消失には至っていないといった 程度の障害は，今回の研究でも高率に見られたもので あり，この程度の障害は回復する可能性を示している と考えられる ${ }^{22)}$.

近年, 有毛紏胞の感覚毛に tip link, side link とい つた微細構造の存在が明らかにされつつある ${ }^{232 \sim 26)}$. 強 大音響によるこれらの微細な楧造物の障害が, disarray やfloppy といった感賞毛の配列の乱れ，つまり 本研究での障害スコア10成因の一つとなっていると も考光られ，有毛細胞障害の可逆性の可能性と関連し て興味がもたれる。

血管条の障害は, 音響負荷直後には, 白色モルモッ ト，有色モルモットいずれも軽度であり，負荷 3 日後 の障害が最も高度となり，7 日後には障害は再び軽度 となっていた。

Duvall ら ${ }^{271}$ は, チンチラに強大音響を負荷し，血管 条形態を経時的に観察している。その障害は音響負荷 1 時間後より現れ，1日後にピークに達し，28日後に ほぼ完全に回復したとしており, 本研究に抢ける結果 も同様であった，つまり，音響負荷直後の物理的エネ ルギーによる血管条の障害は，比較的軽度であるが， 1 日から 3 日の閒に代謝障害が加わることによって， 形態学的異常が最大となるものと考えられた。

有色モルモットと白色モルモットを比較すると，全 経過を通じて有色モルモットの方が障害は軽度であ り，とくに負荷 3 日後における障害の差は明白であっ た。また，有色モルモットでは中間細胞に見られるメ ラニンの, 内リンハ腔側への移動が特徴的であり,こ
のメラニンの移動が血管条障害の軽減と関係している 可能性があるものと思われた。

Ikeda $\check{5}^{28)}$ は，モルモットを用いて音響外傷時の内 リンパ液イオン変化を調ベ，Kイオンと Naイオンの 緩徐な増加とともに，Ca イオンの著明な上昇を音響負 荷後数分で認めたと報告している。こうした内リンパ 液イオンの变化が，内・外有毛細胞の機能に間接的あ るいは直接的に影響を及ぼし聴力の一過性域值上昇の 一翼を担っているものと扰も加れる。

内耳メラニンとCaイオンとの密接な関連につい て, Gottesberge は2930)，メラニンが細胞内に招ける Caイオンの緩衝システムとして働き，細胞内，細胞間 のイオン環境をコントロールするとしている。すなお ち, 血管条内のCaイオンの調整に, メラニンが重要な 役割を果たしていると推測されるもので, 血管条のメ ラニンの存在が，蝸牛に対する音響障害の程度に, $\mathrm{Ca}$ イオンの面から間接的に影響を及ぼすと考えられる。 つまり，Ikeda ら $^{28)}$ の言うように，音響負荷に上り内 リンパ液中のCaイオンが著明に上昇すると，血管条 へのCaイオンの流入が抗こり,血管条内に高 Ca イオ ンの状態が生まれる。このため血管条内のイオンバラ ンスがくずれ，メラニンのない色モルモットでは, 辺縁細胞の核の変形々細胞質の多数の空胞形成, 辺縁 細胞と中間細胞の細胞間㭞の拡大といつた血管条障害 を来すと考光られる。一方, 前述のようにCaイオンの 緩衝作用を有するメラニンが存在する有色モルモット では，本実験で音響負荷直後加ら見られたように，中 間細胞内をメラニンが移動して, 辺縁細胞側人と接近 し, 高 Ca イオン状態の改善へと働き，血管条の障害を 軽減するわけである。

ここで血管条の機能を考えてみると，血管条は，内 リンパ夜の分泌・吸収及びイオン環境維持に極めて重 要な部位であるとともに，有毛細胞の機能維持に重要 な働きを持っていると考えられている 大音響負荷による血管条障害が，メラニンの存在によ り軽減されれぱ, 蝸牛有毛細胞障害とその回復過程に も，間接的になんらかの影響を与えるはずで，その結 果，聴力障害が軽減されるものと思われる。

\section{結語}

血管条にメラニンが存在する有色モルモットとメラ ニンの存在しない白色モルモットに，強大音響 $(4 \mathrm{KHz}, 120 \mathrm{~dB}, 60$ 分) を負荷し, 生理学的, 形態学 的観察を行い以下の結果を得た。 
1）負荷直後，負荷 3 日後，7日後のいずれの時期 に拐いても, 有色モルモットの方が, 聴力障害は, 軽 度であった。

2）外有毛細胞の障害を，スコア化して評価した結 果,有色モルモットの方が障害の程度は軽度であった。

3）有色モルモットの外有毛細胞障害スコアーは, 音響負荷 7 日後の方が, 負荷直後よりも小さく, 外有 毛細胞に障害からの回復能のあることが示唆された。

4）血管条障害は, 負荷 3 日後に最も高度となり, 白色モルモットの障害は有色モルモットの障害よりも 強かった。

5）音響障害下の血管条にみられた特徵的な変化 は, 中間細胞内メラニンの, 内リンパ腔側への移動で あった。

6）これらの結果より，血管条メラニンは，音響障 害に対する防御作用に関与していることが推察され た.

\section{参考文献}

1) Corti A: Recherches sur l'organe de louie des mammiferes. Z Wiss Zool 3: 109-169, 1851 .

2) Conlee JW, Parks TN, Schwartz IR et al : Comparative anatomy of melanin pigment in the stria vascularis. Acta otolaryngol (Stockh) 107: 48-58, 1989.

3) Hilding DA, Ginzberg RD: Pigmentation of the stria vascularis. Acta Otolaryngol (Stockh) 84: 24-37, 1977

4) Wolff $D$ : Melanin in the inner ear. Arch Otolaryngol $14: 195-211,1931$.

5) Cherubino $\mathrm{M}$ (原田康夫訳)：内耳のメラノサイトにつ いて。耳鼻臨床 $62: 508-510 ， 1969$.

6) Attard A, Gratacap B, Charachou R et al : Melanin value in the stria vascularis of pigmented guinea pigs treated by kanamycin. Acta Otolaryngol (Stockh) 105: 507-510, 1988.

7) Schrott A and Spoendlin H: Pigment anomaly associated inner ear deafness. Acta Otolaryngol (Stockh) 103: 451-457, 1987.

8) Crovetto MA, Linthicum FH: Are melanin deposits in the stria vascularis related to cause hearing loss? Revue Laryngo 109 : 453-455, 1988.

9) Bonaccorsi P : Il collore delliride come "Test " di valutazione quantitativa, nell'uomo, della concentrazzione di melanina nel- la stria vascolare. Ann Laryngol $64:$ 725-738, 1965.
10) Carter NL, Keen K, Waugh RL et al : The relations of eye colour and smoking to noise-induced permanent threshold shift. Audiology $20: 336-346,1981$.

11) Tota $G$ and $G$ Bocci: Importance of the color of the iris in the evaluation of resistance of hearing to fatigue. Rev Otoneuroophtalmol 43: 183-192, 1967.

12) Stevens SS, Davis H, Lurie MH : The localization of the pitch perception on the basilar membrane. J Gen Phsiol 13: 297-315, 1935.

13) Greenwood DD: Critical bandwidth and the frequency coordinates of the basilar membrane. J Acoust Soc Am 33: 1344-1356, 1961.

14) Wilson JP, Johnstone JR: Basilar membrane and middle ear vibration in the guinea pig measured by capacitive probe. J Acoust Soc Am 57: 705-723, 1975.

15) Fredelius L, Johansson B, Bagger-Sjoback D et al : Qualitative and quantitative changes in the guinea pig organ of corti after pure tone acoustic overstimulation. Hear Res 30:157-168, 1987.

16) Duvall AJ, Robinson KS: Local vs systemic effects of acoustic trauma on cochlear structure and transport. Arch Otolaryngol Head Neck Surg 113 1066-1071, 1987.

17) $\operatorname{Lim} \mathrm{DJ}$ : Effects of noise and ototoxic drugs at the cellular level in the cochlea. Am J Otolaryngol 7: 73-99, 1986.

18) Saunders JC, Dear SP, Schneider ME: The anatomical consequences of acoustic injury: a review and tutorial. J Acoust Soc Am 78: 833-860, 1985.

19) Engström B, Borg $E$ : Cochlear morphology in relation to loss of behavioural, electrophysiological, and middle ear reflex thresholds after exposure to noise. Act Otolaryngol (Stockh), suppl 402:1-23, 1983.

20) Conlee JW, Abdul-Baqi KJ, McCandless GA et al Differential susceptibility to noise-induced perma. nent threshold shift between albino and pigmented guinea pigs. Hear Res 23: 81-91, 1986.

21) Conlee JW, Abdul-Baqi KJ, Mc Candless GA et al : Effects of aging on normal hearing loss and noiseinduced threshold shift in albino and pigmented guinea pigs. Acta Otolaryngol (Stockh) 106:64 70,1988 .

22) Hunter-Duvar IM : Morphology of the normal and the accustically damaged cochlea. Scanning Elec. tron Microsc II : 421-428, 1977. 
23) Takumida $M$ : Glycocalyx and ciliary interconnections of the vestibular end organs: an investigation by high resolution scanning electron microscopy. ORL $51: 137-143,1989$.

24) Pickles JO, Comis SD, Osborne MP: Cross-links between stereocilia in the guinea pig organ of corti, and their possible relation to sensory transduction. Hear Res 15: 103-112, 1984.

25) Fumess DN, Hackney CM: Cross-links between stereocilia in the guinea pig cochlea. Hear Res 18; 177-188, 1985.

26) Pickles JO, Osborne MP, Comis SD : Vulnerability of tip links between stereocilia to acoustic trauma in the guinea pig. Hear Res 25:173-183, 1987.

27) Duvall AJ, Ward WD, Lauhala KE: Stria ultrastructure and vessel transport in acoustic trauma. Ann Otol 83: 498-514, 1974.

28) Ikeda $K$, Kusakari $J$, Takasaka $T$ : Ionic changes in cochlear endolymph of the guinea pig induced by acoustic injury. Hear Res 32 : 103-110, 1988.

29) AM zum Gottesberge: The role of melanocytes in the pathophysiology of experimental hydrops.
Second International Symposium on Meniere's Disease $343-350,1988$.

30) AM zum Gottesberge: Physiology and patho. physiology of inner ear melanin. Pigment Cell Research 1: 238-249, 1988.

31) Johnstone BM, Sellick PM : The peripheral auditory apparatus. Q Rev Biophys 5: 1-57, 1972.

32) Kuijpers W, Bonting SL: The cochlear potentials II, the nature of the cochlear endolymphatic resting potential. Pflugers Arch 320:359-372, 1970.

稿を終えるにあたりここ指導ならびにご校閲を閖りまし た恩師原田康夫教授に深甚なる謝意を表します、また本研 究に際しご指導，ご助言を頂きました田頭宣治助教授，鈴 木 衞講師，工田昌也助手に深く感謝致します。

本論文の要旨は第16回日本耳鼻咽腹科学会中国地方部会 連含会，第38回日本基整耳科学会にてロ演した。

(1991年9月11日受稿 1991 年11月 7 日受理)

別刷請求先 テ730広島市中区大手町3-4-27

中電病院耳㐭咽邷科 川口和幸 